\title{
CITIZENS AS SOCIAL WORK EDUCATORS IN A POST-CONFLICT SOCIETY. REFLECTIONS FROM NORTHERN IRELAND
}

\author{
JOE DUFFY \\ Lecturer in Social Work. School of Sociology, Social Policy and Social Work. Queen's University. Belfast
} Northern Ireland.

\section{ABSTRACT}

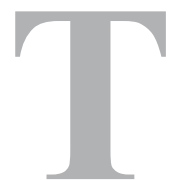

his paper examines how service users and carers can contribute to social work education in a post conflict society. A small-scale study undertaken in Northern Ireland is used as a case study to show how such citizens can potentially critically contribute to social work students' understanding of the impact of conflict on individuals, groups and communities. The need to appreciate the effects of such community division is now a core knowledge requirement of the social work curriculum in Northern Ireland.

The article reports on research findings with service users, carers and agency representatives which points to ways in which social work students can achieve a critical understanding of the impact of conflict. Northern Ireland, in this way, is presented as a divided society, still in a state of adjustment and evolution, following a period of protracted community strife and violence.

The author suggests that individuals who have been directly affected by conflict can contribute in an informed and critical way to social work students' developing knowledge and experience in an important area of their professional competence and understanding of anti-oppressive practice more broadly.

Key words: Service user, carer, post conflict, social work education, citizen.

\section{RESUMEN}

LOS CIUDADANOS COMO EDUCADORES DE TRABAJO SOCIAL EN UNA SOCIEDAD POSCONFLICTO

El presente artículo analiza el modo en el que cuidadores y personas dependientes pueden contribuir a la educación en trabajo social en una sociedad posconflicto. Un estudio realizado a pequeña escala en Irlanda del Norte se toma como estudio de caso para mostrar 
cómo estos ciudadanos podrían contribuir en gran manera a que los estudiantes de trabajo social comprendan el impacto del conflicto sobre los individuos, grupos y comunidades. Conocer los efectos producidos por esta división de la comunidad se ha convertido ahora en un requisito indispensable para el currículo de trabajo social en Irlanda del Norte.

El artículo expone los resultados obtenidos a través de investigaciones realizadas con personas dependientes, cuidadores y representantes de organismos que desvelan de qué modo los estudiantes de trabajo social pueden conocer cuáles son las consecuencias del conflicto. A este respecto, Irlanda del Norte se presenta como una sociedad dividida, todavía en un estado de adaptación y evolución, tras una etapa prolongada de violencia y conflicto comunitario.

El autor señala que los individuos que se han visto directamente afectados por el conflicto pueden contribuir de un modo crucial y bien fundado a que los estudiantes de trabajo social adquieran una mejor comprensión y experiencia en un área importante de su competencia profesional y a que entiendan de manera más general las prácticas anti-opresivas.

Palabras clave: persona dependiente, cuidador, posconflicto, educación en trabajo social, ciudadano.

\section{INTRODUCTION}

Until the reform of social work training resulting in the Bachelor of Social Work Degree in 2004, the social work curriculum in Northern Ireland did not have a mandatory requirement for students to address issues associated with the conflict. Before this, social work students needed only to demonstrate awareness of issues around anti-racist and antioppressive practice as a broader element of understanding social work values.

However, the background of community violence raging in Northern Ireland, euphemistically known as the Troubles, often presented particular difficulties around open discussion on controversial and divisive issues such as sectarianism, indeed to do so would have been dangerous in many circumstances (Smyth and Campbell, 1996). For its part, the public sector response in Northern Ireland, the main employer of social workers, was to adopt a policy stance of neutrality, which although easy to criticise, for many provided a safe working culture from the devastation going on in the background.

Whilst social work training promoted anti-racist and anti-discriminatory perspectives, issues concerning anti-sectarian approaches presented as more difficult and challenging. In 1999, however, a momentum for change was heralded by the Central Council for the Education and Training of Social Workers (CCETSW) publication Getting Off the Fence. This provided a range of standards in social work practice and training which offered guidance to Northern Ireland's social workers on how to examine aspects of sectarianism in a more open and safe environment. This would also help in offering social work practitioners, social work students and professional educators much needed support in response to the uncertainties they all voiced about being ill-equipped in responding to and dealing with sectarianism (CCETSW, 1999). By 2004, the Degree in Social Work was introduced at a time of relatively sustained peace and normality in Northern Ireland. This qualification signalled more creative thinking around embedding issues associated with the 'Troubles' at the heart of social work education where students would be required to demonstrate an understanding of what is referred to as 'the Northern Ireland Context'. The Northern Ireland Social Care Council (NISCC), the regulatory Body for social work in Northern Ireland, in its Framework Specification for the Social Work Degree stipulated that: 
"...the impact of past and current violence, conflict and divisions in Northern Irish society requires particular emphasis in the education and training of social work students in Northern Ireland." (DHSSPS, 2003:6)

In specifying this further as an element of underpinning knowledge, this document also indicated the need for students to understand:

"...the personal and community consequences of the Northern Ireland conflict for individuals, families, groups, and communities and the implications for social work practice”. (DHSSPS, 2003:16)

The NISCC provided curriculum guidance on how this could be achieved but what was less explicit in this material was any reference to how service users and carers could contribute to this important area. In contrast, however, service users and carers are expected to be involved in every other aspect of Social Work Degree provision, similar to requirements in other parts of the United Kingdom.

In order to investigate this area, the author undertook research to develop good practice guidance on ways in which service users and carers as citizen trainers could contribute to social work training generally but with a specific focus on how the user perspective could also enhance students' understanding of the Northern Ireland Context. The findings from the work are expanded upon in this discussion. Before this however, it is important to set the scene for this research by briefly outlining key historical milestones in social work education in Northern Ireland and how participation in social work education has become more important during this period.

\subsection{Northern Ireland, a place apart?}

Northern Ireland is a society emerging from a violent conflict lasting over 30 years which has left more than 3700 dead, many thousands injured and many people and communities deeply traumatized and psychologically injured (Fay et al, 1999). Until the signing of the peace accord known variously as the Good Friday/Belfast Agreement in 1998, Northern Ireland, to many observers, was viewed as a place apart in the United Kingdom. It was regarded as being one of the most violent societies in Western Europe, having endured a protracted period of conflict dating back to the partition of Ireland in 1921 (Campbell and Mc Colgan, 2001). With a population of over 1.7 million people, Northern Ireland is part of the United Kingdom but constitutionally separate from the Republic of Ireland. Both citizenship and political identity have therefore been contested issues in Northern Ireland since partition from the rest of Ireland (Campbell, 1998) with a large minority of Catholics seeing themselves as Irish, and a Protestant majority which perceives itself as British (Arlow, 2002).

In spite of these difficulties, the 1998 Peace Agreement was designed to represent a new beginning with the signatory governments of the United Kingdom and Ireland underscoring a commitment to "...dedicating ourselves to the achievement of reconciliation, tolerance, mutual trust, and to the protection and vindication of the human rights of all. "(Governments of UK and Ireland, 1998). Northern Ireland, however, has not enjoyed, until very recently, the stability that was the vision of those who signed this Agreement. Instead, there have been fluctuations between devolved local government and Direct Rule from London and a continuing level of background community violence, albeit on a considerably decreased level than was the case previously. For its part, social work has not been unaffected by these circumstances. 


\subsection{Social Work and the conflict in Northern Ireland}

Referring to social work in Northern Ireland, Ramon et al observe "...the role social workers have played in the conflict has, until recently, been under-researched" (2006:3). What we do know is that social work, like other professions, has had to cope with the uncertainties and complexities around service delivery in a divided and contested society. For example, in the early days of the 'Troubles', social work practice had to respond to large-scale population movements, intimidation of families and the influence of paramilitary organizations (Williamson and Darby,1978 in Campbell and Mc Colgan, 2001). McColgan vividly portrays the challenges to social workers in these situations:

"...the Troubles were not an entity but a series of situations which demanded different organizational responses and the ability of staff and managers alike to adapt to change.

The disturbances have ranged from riots where families had been intimidated out of their homes or left voluntarily, to evacuations of children and families to rural areas, the use of car bombs, bomb scares, assassinations, the introduction of internment, 'no-go areas', workers' strikes, and the closure of social services departments within politically sensitive areas." (1998:99)

Some commentators suggest that the imposition of Direct Rule in Northern Ireland by the UK Government in 1972, and the creation of integrated systems of health and social welfare, gave rise to technocratic \{my emphasis\} approaches to service delivery which made it difficult for social workers to address complex issues such as sectarianism in particular (Pinkerton, 1998; Pinkerton and Campbell, 2002).

For example, Pinkerton (1998:22) contends instead that “...this 'technocratisation' of services ...provided an environment in which staff coming from both sides of the community could distance themselves from the sectarianism of the wider society and develop a nonsectarian professional identity". Smyth and Campbell (1996) describe this distancing of the social work profession's response as "...an ideology of benign detachment, which failed to address the insidious effects of sectarianism on practice” ( $\mathrm{p}, 90)$.

It is equally argued, however, that a reluctance to take on controversial issues such as sectarianism was understandably related to a pervading fear of death and injury, given that social workers themselves mostly came from the communities affected by the conflict (Campbell and McColgan, 2001).

Having said this, with the advent of more peaceful times from the mid nineties following the paramilitary ceasefires, social workers arguably felt more comfortable about addressing and openly discussing controversial issues. CCETSW's (1999) publication of standards in practice and training, mentioned earlier, offered useful suggestions as to how agencies might examine aspects of sectarianism in a more open, safe environment. By 2004, the Degree in Social Work was introduced at a time of relatively sustained peace and normality in Northern Ireland and endorsed this openness even further with an explicit acknowledgement that the social work curriculum needed to include reference to the Northern Ireland Context.

The complex challenges facing student social workers in this area cannot be understated but what is important is the possibility for students to feel safer to engage in the sort of deliberative and reflective dialogue that discussion on divisive and contested issues demand. As part of their Degree studies, it is therefore hoped that the reform of social work education will see the emergence of new forms of progressive social work knowledge which encourages practitioner engagement with service users and communities in a way that was hitherto fraught with difficulty and danger.

Although this knowledge is a unique requirement for social work students in Northern Ireland, the Social Work Degree in all parts of the United Kingdom has very definite expectations around user participation. 


\subsection{The Social Work Degree: new opportunities in social work education?}

The road to changing and modernizing social work training in the United Kingdom began with the publication of the government document A quality strategy for social care in 2000. This was concerned with improving standards in social care generally, and paved the way for the eventual registration of the social care workforce in the UK. More importantly for this debate, however, was the fact that service user and carer/citizen involvement was to become a central plank of social work education as part of the commitment to treating “...service users and carers as active participants in service delivery rather than as passive recipients” (Levin, 2004:9).

The Northern Ireland Social Care Council (NISCC) also endorsed the centrality of this user perspective as an essential and active part of social work education for students (NISCC, 2003). While social work educators in Northern Ireland were provided with ideas and suggestions by NISCC for delivering the social work curricular requirements around the Northern Ireland Context, there was no direct reference to the potential contribution of service users and carers to this important area, which seemed inconsistent with the importance of the user/citizen perspective advocated in all other aspects of social work education.

To address the latter deficit, Duffy (2006) published good practice guidelines for effectively advancing the involvement of service users and carers in their role as social work educators. A particular emphasis of this study was to examine the potential role that citizens as trainers could occupy in assisting with students' understanding about the impact of conflict on ordinary citizen's lives. In order to develop the basis for these guidelines, research was conducted among a number of key interests in Northern Ireland. This work was funded by SWAP, the Subject Centre for Social Policy and Social Work based at the University of Southampton, the Social Care Institute for Excellence, London (SCIE) and the Northern Ireland Social Care Council, Belfast (NISCC).

This publication refers to service users (social work clients) and carers as citizens as a reflection of both the increasing preference of this terminology by user movements and authors on the subject. Furthermore, the term citizen more appropriately reflects the egalitarian basis and principles informing the work of the user movement (Citizens as Trainers Group et al, 2004). This usage also emphasizes the active social, political and civil rights of service users and carers as opposed to such people being defined by their passive receipt of services (Levin, 2004). Quintessentially however, using the term citizen in this more mainstream way also mirrors fundamental social work values about treating users and carers as equals with rights, duties and expectations around minimum standards of welfare services (Thompson, 2000; Adams et al, 2002).

\section{METHODOLOGY}

Four instruments were designed to investigate this area in terms of establishing generic good practice indicators in user involvement in social work education. Service users and carers were fully involved in the design of these through influencing the wording of the questions, piloting the instruments, analysing the findings and commenting on the accessibility of the report at key stages. The views of key informants were captured from several stakeholder groups with interests and experiences relevant to the area under investigation. In order to obtain a breadth of information, a combination of methodological approaches were applied as this is an important way of ensuring validity in such qualitative research (Belcher, 1994 in Alston and Bowles, 2003).

Firstly, a questionnaire was used to elicit views about good practice in the area of service user and carer involvement in social work education. Themes included ways in which 
service users could be involved in social work education as well as examining at how they could be supported in this task. Questions were also included about the contribution of service users and carers in the area of anti discriminatory practice, and their management of these complex issues in Northern Ireland. The questionnaire was administered by e-mail to social work students, social work lecturing staff at the two main universities in Northern Ireland, practice teaching staff in the country's four Health and Social Services Boards, user-led groups, carer organisations, and the Social Services Inspectorate (SSI). A number of service user groups chose to complete the questionnaire collectively as a reflection of their views and preparatory, explanatory meetings took place in advance with such groups and afterwards for discussion purposes. The total number of questionnaire responses from across these groups was eighty five $(n=85)$.

Secondly a structured instrument was sent by e-mail to a sample of twenty-four $(n=24)$ key informants, including social work training managers, staff responsible for policy and other staff involved in post qualifying training. Respondents were asked to identify their perception of good practice in this field and how citizen trainers might contribute in their role to the Northern Ireland Context. Follow up interviews were then conducted in person or by telephone to clarify responses.

Thirdly, a questionnaire was sent by email to four $(n=4)$ practice teachers from each Health and Social Services Board Area in Northern Ireland. These practice teachers were selected on the basis of their current practice learning involvement with social work students. They were asked to comment specifically on how service users might be involved in practice learning.

Finally, thirteen user and carer-led groups and individuals were invited to construct their own case study material depicting their involvement in different aspects of social work education $(\mathrm{n}=13)$.

\section{FINDINGS}

The findings culminated in the development of key good practice themes which emerged from the data collected. These are detailed as follows, however for the purpose of this paper, specific attention will focus on the Interview findings which concentrate specifically on issues around service users and carers helping students understand conflict related issues.

Good Practice Themes:

1. The inclusion of service users and carers has an invaluable influence and benefit for social work training.

2. Service users and carers need support to train and educate social work students.

3. Service users and carers should be actively involved in the assessment of Practice Learning.

4. Service user and carer involvement in social work education should be grounded on social work values.

5. Service users and carers should be involved in all aspects of teaching, learning and assessment.

6. Service users and carers have an important strategic role to play in social work training in Northern Ireland.

7. Service users and carers have an important contribution to make to facilitate students in their understanding of the Northern Ireland Context.

(Duffy, 2006:35) 


\subsection{Interview Findings $(n=24)$}

Whereas the questionnaire included some questions focussing on the potential capacity for service users and carers to participate and engage with issues concerning different manifestations of discrimination in the teaching context, the Interview concentrated more directly on how such citizens could contribute to social work students' understanding of the Northern Ireland Context as one particular aspect of this.

The view that Northern Ireland is now perceived as being a more stable/normal context for such contributions was acknowledged by one respondent: "service users might now feel more comfortable about sharing information about how the Troubles have affected them..." This however is qualified by a reminder of how dangerous such openness may have been during the 'Troubles': "...which is different from the past when this was dangerous because of people's worries about their own security amidst the conflict."

On a similar experiential theme, some service user/carer group respondents indicated that their lived experiences of caring responsibilities arising as a direct consequence of The Troubles (for example physical and psychological traumas) could also be shared by citizen trainers in a way that would help students understand this role: "perhaps people could talk about having to care for a relative who was in some way caught up in the troubles" Continuing with practical ideas for enabling social work students in their understanding of how conflict affected ordinary people's lives, another respondent suggested informing social work students about how daily living choices in regard to public services were affected by the Troubles:

"Service users and carers could talk about being unable to access services because of the area they were located in" (Interview Respondent) Other research studies in this area have used the term chill factor to describe the discomfort and unease sometimes identified by people in relation to going into areas where they felt unsafe (McAleavey et al, 2001; Dunn and Gallagher, 2002).

Another commentator cautioned that citizens in this education role needed also to be "open to calling themselves both victims and victimisers" in the Northern Ireland conflict (Interview Respondent). A service user also comments on this point that "it is okay to hold certain views about the Troubles but care is needed to make sure that these views don 't cause an adverse reaction..." this respondent goes on to highlight the importance of citizen contributors being self-aware in this process: “...training around awareness of our own issues may well address and prevent this" which is a similar point made earlier about social work students needing to exercise similar self-awareness in terms of their own experiences, issues and prejudices.

\section{DISCUSSION}

The findings from this small-scale study would suggest that citizens can make an important contribution in several key knowledge domains of social work education in Northern Ireland. This key conclusion reinforces existing evidence about the value of the user perspective in social work education (Beresford, 1994; Levin, 2004; and GSCC, 2004) and the significance of its contribution to theorising in social work and social policy more broadly (Beresford, 1999). The preparedness and ability to teach on issues associated with discrimination and oppression are particularly noted by service users, carers, social work students and other stakeholders. The experiences of being on the margins, as one service user describes it, is portrayed by many respondents as informatively enabling social work students to understand the meaning of oppression in peoples' lives. Again, this has already been noted by authors such as the Citizens as Trainers Group et al who observed that issues concerning oppression were major contributory forces in the lives of service users. They 
suggest that this experience can be used in a constructive way: "our work must challenge all forms of oppression whether by reason of race, gender, sexual orientation, age, class, disability or any other form of social differentiation..." (2004: 315).

As a key dimension of this latter point, the findings from this work particularly suggest that service users and carers have an important contribution to helping social work students understand the meaning of the Northern Ireland Context. Whilst the challenges inherent in this type of involvement are not be underestimated, given that discussion on such emotive issues can result in strain and discomfort in student interactions (Garcia and Van Soest, 1997; Hyde and Ruth, 2002; Tatum, 1992; Van Soest, 1994), perhaps this type of open involvement and discussion of contested issues meets the call by Pinkerton and Campbell(2002) for social work in Northern Ireland to embrace more innovative and progressive modes of practice in a climate of peace.

Many respondents in this study however indicate the importance of training as a way of supporting service users in their contributions to social work education. This is already well documented in previous work in this area (Beresford, 1994; Levin, 2004; Duffy, 2006) but would seem to have particular relevance in regard to preparing and supporting citizen trainers for involvement in discussion around contested issues. The findings also suggest that social work students need to engage in self-awareness and reflection as part of their own preparation in terms of involvement with citizens as educators. These observations are also confirmed by previous work in this area which indicates that service users are effectively engaging in a discourse that is central to the development of critical reflection (Ford et al, 2006) in social work students (Clarke, 2000).

Notwithstanding this, comments were made by social work students and service users themselves in this study about the user perspective being perceived as having lesser intellectual value. This is also intimated in the literature by some commentators who express scepticism about "ordinary people taking on powerful roles" (Rimmer, 1997:33; Beresford \& Croft). Social work students also suggested that citizen trainers could be unfairly treated in the teaching role because of stigmatising perceptions associated with their background. Again, this has been noted in other work on this area such as the GSCC review of user involvement in Social Work Degree programmes in the United Kingdom where sometimes service users in their role as trainers experienced patronising treatment by some social work students (GSCC, 2004). This would seem to suggest that training is important for everybody involved in advancing user involvement initiatives as has already been suggested (See Levin, 2004).

Admittedly, whilst there is dearth of research material on the impact of political conflict on social workers and service users, the findings and suggestions emerging from this small-scale study indicate that individuals who have been directly affected by conflict can potentially contribute in a critical and informed way to social work students developing knowledge in a key area of professional competence. These findings may equally have the potential to apply to social work education in other parts of the world where violence characterises the backdrop to social work training.

\subsection{International perspectives}

Research conducted among social workers engaging with service users in other global contexts characterised by violent political conflict cites similar experiences that could potentially contribute to social work students' acquisition of important insights. For example, Ramon (2004) studied the impact of the Israeli/Palestinian conflict on service users through consulting a wide range of social workers. The following problems were identified as featuring prevalently for service users in this study: "living in fear and increased anxiety (...). Learning to live with the traumatic impact of the loss of a loved one 
or a physical injury (...) problems associated with grief and bereavement... Older people (especially Holocaust survivors), children and men seem to be more adversely affected by the conflict" (cited in Ramon et al 2005:8). An interesting point, and maybe one that is often overlooked, is also made however by social workers in this study about the cohesive effect which community violence had by bringing families and communities together in a more mutually supportive manner.

A similar study by Lindsay and Baidoun (2004) looking at the impact of the Palestinian conflict noted the frustrations expressed by service users about difficulties getting to and from work due to the frequency of checkpoints and road closures. Both of these studies significantly conclude that "living in societies where political conflict becomes prolonged inevitably impacts negatively (...) on ordinary citizens and users of health and social care..." (Ramon et al, 2005:12).

In sensitising qualifying social workers to the magnitude of how such division impacts on service users, perhaps progress can be made towards helping social workers better understand and appreciate the contribution they can potentially make to political conflict resolution. Nevertheless, such initiatives need to be endorsed and supported at a structural level to avoid limiting and hampering the effectiveness of social work practice in violent contexts (Cohen, 2001 in Ramon et al, 2005).

\subsection{Case Study}

Currently at Queen's University in Belfast, Northern Ireland we have been piloting the involvement of service users who have had direct personal experience of being affected by Northern Ireland's conflict in the teaching of social work students. These individuals have been injured, traumatised and bereaved through the 'Troubles' and have been sharing their experiences with first year social work students as a way of preparing them for the skills they need to be aware of when working with service users who have had similar type experiences. What this involves in the classroom situation is students working n pairs discussing their understanding and fears of 'the other' whereby they have opportunities to explore stereotypes and histories. Through use of case study material prepared in advance, social work students and the service users discuss together ideas around developing skills of engagement and communication in working with victims and survivors of the conflict. This also gives opportunities for the students to hear perspectives from citizens who have been 'hard to reach/seldom heard' and for the mutual exploration of feelings thoughts and behaviours. In order to ensure that this is a safe and supportive learning space for all of the participants it is important that these sessions are all meticulously planned. The social work teaching staff therefore hold several preparatory meetings with the service users before the teaching whereby there is an agreed approach to the teaching. Additionally a learning contract is agreed with the students which reflects important issues such as confidentiality, privacy, support and professional behaviour.

\section{CONCLUSION}

The main conclusion from this small study was the overwhelming support existing across Northern Ireland for involving service users and carers in all aspects of social work training. More specifically however, the findings formed the basis for the development of key Good Practice Themes and Guidelines around the involvement of citizens in social work education, one of which, the Northern Ireland Context and associated issues around anti-oppressive practice are expanded upon. This paper has presented the findings of a small-scale piece of research conducted among relevant stakeholders in Northern Ireland that forms the basis for good practice guidelines in the involvement of service users and carers as citizen trainers in social work education. For the purpose of this article however, 
one aspect of good practice in this regard has been emphasized, i.e. the way such citizens can assist social work students in their understanding of how community division and violent conflict can affect individuals and communities.

Such citizen trainers are demonstrating that they can make a valuable contribution to the quality of social work education. An opportunity now presents itself in a more peaceful Northern Ireland for citizens to assist social work students in their understanding of the Northern Ireland Context. This research has generated some pragmatic suggestions for achieving this understanding which should facilitate such students in their understanding of anti-oppressive perspectives more generally. The challenges inherent in this work are not underestimated and, indeed, all of the actors in this endeavour need support.

The potential outcomes however are considerable for social work students nationally and internationally, as the role that citizens occupy in assisting their understanding of complex issues is significantly advanced.

\section{REFERENCES}

ADAMS, R.; DOMINELli, L; PAYNe, M. (2002): Critical Practice in Social Work. Basingstoke. Palgrave.

ALSTON, M.; BOWLES, W. (2003): Research for Social Workers. An introduction to methods. 2nd edition. London and New York. Routledge Taylor and Francis Group.

ARLOW, M. (2002): The Development of Education for Democratic Citizenship in Northern Ireland accessed at www.ibe.unesco.org/curriculum/Balticpdf/northern_ireland.pdf

BELCHER, J.R. (1994): "Understanding the process of social drift among the homeless: a qualitative analysis" in Qualitative Research in Social Work, E. Sherman \& W.J. Reid (eds.), New York, Columbia University Press.

BERESFORD, P.; CROFT, S. (1993): Citizen Involvement: A Practical Guide for Change, Basingstoke, Macmillan.

BERESFORD, P.; PAGE, L.; STEVENS, A. (1994): Changing the culture: Involving service users in social work education, CCETSW Paper 32.2, London: Central Council for Education and Training in Social Work.

BERESFORD, P. (1999): Service Users Knowledges and Social Work Theory: Conflict or Collaboration? 26th May 1999, Brunel University, Seminar Topic.

CAMPBELL, J. (1998): 'Social Policy and Social Work in Northern Ireland' in Social Work and Social Change in Northern Ireland. Issues for Contemporary Practice (CCETSW. 1998. ch. 1, p. 4 -15).

CAMPBElL, J.; Mc COLGAN, M. (2001): "Social Work in Northern Ireland" in M. Payne, and S. Shardlow, (eds) Social Work in the Western Isles of Europe. London: Jessica Kingsley.

CCETSW (1999): Getting Off the Fence: Challenging Sectarianism in Personal Social Services. London: Central Council for Education and Training in Social Work.

CITIZENS AS TRAINERS GROUP, Young Independent People Presenting Educational Entertainment, Rimmer, A and Harwood, K (2004): Citizen Participation in the Education and Training of Social Workers. Social Work Education, vol. 23, no. 3, June 2004, pp. 309-323.

CLARKE, S. (2000): Social Work as Community Development: A Management Model for Social Change, Aldershot. Ashgate.

COHEN, S. (2001): States of Denial: Knowing about Atrocities and Suffering, London, Polity Press.

DH (Department of Health) (2000): A quality strategy for social care, London: DH.

DHSSPS (2003): Northern Ireland Framework Specification for the Degree in Social Work. Belfast. 
DUFFY, J. (2006): Participating and Learning: Citizen Involvement in Social Work Education in the Northern Ireland Context. A Good Practice Guide. London: Social Care Institute for Excellence/Social Work and Social Policy (SWAP)/Northern Ireland Social Care Council (NISCC). http://www.scie.org.uk/publications/misc/citizeninvolvement.pdf.

FAY, M.T.; MORRISSEY, M.; SMYTH, M. (1999): Northern Ireland's Troubles: The Human Costs. London: Pluto.

FORD, P.; JOHNSTON, B.; MITCHELL, R.; MYLES, F. (2004): “Social Work Education and criticality: some thoughts from research”. Journal of Social Work Education, vol. 23, Issue 2, April 2004, pp. 185-198.

GARCIA, B.; VAN SOEST, D. (1997): "Changing Perceptions of Diversity and Oppresssion: MSW Students Discuss the Effects of a Required Course", Journal of Social Work Education, vol. 33, Winter, pp. 119-129.

GENERAL SOCIAL CARE COUNCIL (2004): Working towards full participation. A report on how social work degree courses, which started in 2003, have begun to involve service users and carers in social work training.

GOVERNMENTS OF UK AND IRELAND, (1998): The Agreement, Northern Ireland Office.

HYDE, C.A.; RUTH, B.J. (2002): "Multicultural Content and Class Participation: Do Students SelfCensor?” Journal of Social Work Education, vol. 38, no. 2, pp. 241-256.

LEVIN, E. (2004) Involving service users and carers in social work education. London. Social Care Institute for Excellence.

LINDSAY, J.; BAIDOUN, N. (2004): An exploration of the experience of Palestinian practitioners during the 2nd Intifada, paper presented at the conference on International Social Work, Adelaide, October.

MC COLGAN, M. (1998): "Issues for Social Work Practice with Families and Children in Northern Ireland" in Social Work and Social Change in Northern Ireland. Issues for Contemporary Practice (CCETSW. 1998. ch. 1, p. 96 -108).

NISCC (2003): Rules for the Approval of the Degree in Social Work. Belfast. Northern Ireland.

PINKERTON, J (1998): "Social Work and the Troubles: New Opportunities for Engagement" in Social Work and Social Change in Northern Ireland. Issues for Contemporary Practice (CCETSW. 1998. ch. 1, p. $15-30)$.

PINKERTON, J.; CAMPBELL, J. (2002): "Social Work and Social Justice in Northern Ireland: Towards a New Occupational Space”. British Journal of Social Work, vol. 32, pp. 723-737.

RAMON, S. (2004): “The Impact of the 2nd Intifada on Israeli Arab and Jewish Social Workers". European Journal of Social Work, 7(3), pp. 285-303.

RAMON, S.; CAMPBELL, J.; LINDSAY, J.; Mc CRYSTAL, P.; BAIDOUN, N. (2006): “The Impact of Political Conflict on Social Work: Experiences from Northern Ireland, Israel and Palestine". British Journal of Social Work, 2006, 36(3): 435-450. Oxford University Press.

RIMMER, A. (1997): "Power and Dignity: Women, poverty and credit unions". Gender and Development, 5 , no. 3 .

SMYTH, M.; CAMPBELL, J. (1996): "Social Work, Sectarianism and Anti-Sectarian Practice in Northern Ireland”, British Journal of Social Work.

TATUM, B.D. (1992): “Talking about Race, Learning about Racism: An Application of Racial Identity Development Theory in the Classroom". Harvard Educational Review, vol. 62, no. 1, pp. 1-24.

THOMPSON, N. (2000): Understanding Social Work, Preparing for Practice, Palgrave, Basingstoke.

VAN SOEST, D. (1994): "Social Education for Multicultural Practice and Social Justice Advocacy: A Field Study of How Students Experience the Learning Process". Journal of Multicultural Social Work, vol. 3 , no. 1, pp. 17-28.

WILliAMSON, A.; DARBY, J. (1978): “Social Welfare Services” in J. Darby and A. Williamson, Violence and the Social Services in Northern Ireland, London: Heinemann. 